\title{
LA GESTIÓN DEL MIEDO POR LA IGLESIA CATÓLICA ESPAÑOLA EN LOS MANUALES DE RELIGIÓN: CAMBIOS Y CONTINUIDADES QUE IMPLICA EL CONCILIO VATICANO II
}

\author{
The Management of Fear by the Spanish Catholic Church \\ in the Textbooks of Religion: Changes and Continuities resulting \\ from the Second Vatican Council
}

\section{Emilio Castillejo Cambra*}

Fecha de recepción: 15/03/2015 • Fecha de aceptación: 03/05/2015

Resumen. El presente artículo, a través de boletines oficiales eclesiásticos y manuales de Religión, compara la gestión del sentimiento del miedo que hace la Iglesia católica española antes y después del Concilio Vaticano II. Comprueba la erosión de los miedos naturales, a las epidemias, el hambre, la guerra... (la humanización de Dios no parece compatible con su ira), de los miedos escatológicos, donde más pesaban los elementos sensitivos del miedo (la repolitización de la religión católica sitúa el miedo cada vez más en lugares profanos), o incluso el miedo al otro no católico (ecumenismo). Pero comprueba también, especialmente en los manuales de la Iglesia neointegrista, el mantenimiento de otros miedos inducidos, donde se imponen claramente los elementos cognitivos del miedo: miedo a la secularización de la ciencia y del pensamiento, a la pérdida de influencia en la sociedad, a las novedades del Concilio Vaticano II, a la teología de la liberación, al laicismo o a la pérdida de la protección del Estado con que cuenta la Iglesia católica española. Es problemático, por tanto, afirmar, como hacen algunos autores, que el Concilio Vaticano II supone el paso de una institución estatalmente orientada a otra orientada a la sociedad.

Palabras clave: Miedos naturales. Miedos inducidos. Iglesia católica española.Educación religiosa. Manuales de Religión católica.

Abstract. This article uses ecclesiastical records and textbooks of Religion to make comparisons regarding the way in which the Spanish Catholic Church

\footnotetext{
* Centro de la UNED de Pamplona. C. Sadar, s/n. 31006 Pamplona. Navarra. España. ecastillejo@pamplona.uned.es
}

Cómo citar este artículo: Castillejo Cambra, Emilio. «La gestión del miedo por la Iglesia católica española en los manuales de religión: cambios y continuidades que implica el Concilio Vaticano II», Historia y Memoria de la Educación, 2 (2015): 161-194. 
administered the emotion of fear before and after Vatican Council II. We see evidence of the erosion of natural fears: epidemics, hunger, war... (the humanization of God does not seem compatible with his anger), of scatological fears, where the sensory elements of fear weigh most heavily (the repoliticization of the Catholic religion increasingly puts fear in more profane places), or even the fear of the non-Catholic other (ecumenism). But the texts also corroborate, especially in the neo-integrationist Church manuals, the perseverance of other induced fears, where the cognitive elements of fear are clearly imposed: fear of the secularization of science and of thought, of the loss of the Church's influence in society, of the reforms coming from Vatican Council II, of the theology of liberation, of secularism or of the loss of the state protection that the Spanish Catholic Church had always enjoyed. As a result we find it contentious to state, as some authors do, that the Vatican Council II signaled a change from a Stateoriented institution to a society-oriented one.

Keywords: Natural fears. Induced fears. Spanish Catholic Church. Textbooks of Catholic Religion

El ser humano es "sentimentalidad inteligente». ${ }^{1}$ "No hay no sentimiento", que es un estado del sujeto provocado por la imagen que éste crea de un objeto. No es posible enfocar los sentimientos sin una teoría sobre quién, cómo y para qué los usa. ${ }^{2}$

El miedo es un sentimiento poderoso. Nuestro carácter determina la predisposición genética al miedo; pero el miedo puede también aprenderse: ${ }^{3}$ es lo que facilita su uso. El miedo está en el origen de la religión: en las tribus primitivas el rito alivia la existencia, el terror a la historia. ${ }^{4} \mathrm{La}$ confesión en el mundo católico históricamente ha tranquilizado los espíritus y las conciencias. ${ }^{5} \mathrm{El}$ pastor de almas toma su materia prima de las necesidades y temores del entorno laico: ${ }^{6}$ ofrece el sentimiento contrario al miedo, la esperanza. A pesar de todo, la religión no ha sido capaz de eliminar el miedo. Quizás porque, como subrayó Nietzsche, las religiones, alejadas de la vida, sitúan el centro de gravedad en la «mentira de la inmortalidad». ${ }^{7}$

\footnotetext{
1 José Antonio Marina, Ética para náufragos (Barcelona: Anagrama, 1995), 19.

2 Carlos Castilla del Pino, Teoría de los sentimientos (Barcelona, Tusquets, 2009), 37.

3 José Antonio Marina, Anatomía del miedo. Un tratado sobre la valentía (Barcelona: Anagrama, 2013), 98-101.

4 Mircea Eliade, El mito del eterno retorno. Arquetipos y repetición (Madrid: Alianza, 1985), 88, 140-141, y Mito y realidad (Madrid: Guadarrama, 1973), 200-201.

5 Jean Delumeau, La confesión y el perdón (Madrid: Alianza, 1992), 37-44, 146.

${ }^{6}$ Max Weber, Sociología de la religión (Madrid: Istmo, 1997), 134-135.

7 F. Nietzsche, El Anticristo (Madrid: Edimat Libros, 2011), 47, 83.
} 
Quizás porque, más que ayudar a la supervivencia de los hombres, las religiones están diseñadas para asegurar la supervivencia de la religión misma. ${ }^{8}$ Quizás porque las religiones también utilizan el miedo: «religio esse non potest ubi metus nullus est», "no puede haber religión sin miedo» (Lactancio dixit).

También la filosofía pretendió desde sus orígenes aliviar el miedo. Aristóteles define el miedo como «la espera de la desgracia»: la valentía es el término medio virtuoso entre la cobardía y la temeridad. ${ }^{9}$ Estoicos y epicúreos consideran las pasiones como errores en el juicio. La solución de Epicuro es la akataplexía, la inalterabilidad. La solución del estoicismo es la apátheia, el apartamiento de las pasiones y la fortaleza para vivir conforme a las reglas de la naturaleza. ${ }^{10}$ Para Séneca, esa conformidad con la naturaleza nos permite superar el miedo a la muerte, la enfermedad, el futuro,... ${ }^{11}$

Para Spinoza, el miedo es «tristeza inconstante» pues surge de una idea «de cuyo resultado tenemos alguna duda»; por la misma razón, la esperanza es «alegría inconstante»: miedo y esperanza no pueden darse sin tristeza. En cambio, los sentimientos de seguridad y desesperación coinciden en la ausencia de duda. La solución no es eliminar los afectos, sino afectos más potentes que potenciarán el conatus o acción para permanecer en el ser. ${ }^{12}$ En todo caso, autores como Olbeth Hansberg ponen en duda que el miedo proceda de la incertidumbre: uno puede tener miedo por la certeza de la muerte o del dolor. ${ }^{13}$ Por eso, el hombre siente miedo. Para Hobbes, el miedo es determinante tanto en estado de naturaleza como en la sociedad civil posterior al pacto social: en estado de naturaleza, todos los hombres pretenden las mismas cosas y generan un estado de guerra; constituida la sociedad civil, la pasión «que menos inclina a los hombres a quebrantar las leyes es el miedo». ${ }^{14}$

\footnotetext{
8 Richard Dawkins, El espejismo de Dios (Madrid: Espasa, 2007), 188-208.

9 Aristóteles, Ética Nicomaquea. Ética Eudemiana (Madrid: Ediciones El País, 2010), 106-110.

10 Victoria Camps, Breve historia de la ética (Barcelona: RBA, 2013), 84-89.

11 Séneca, Sobre la felicidad, De la brevedad de la vida, Sobre la Clemencia, Ideario, Cuestiones Naturales (Madrid: Ediciones El País, 2010), 64-66, 77-78, 262-286.

12 Baruch Spinoza, Ética demostrada según el orden geométrico (Madrid: Editorial Trotta, 2000), $172,216$.

También G. Kaminsky, Spinoza: la política de las pasiones (Buenos Aires: Gedisa, 1990), 61-64.

13 Victoria Camps, El gobierno de las emociones (Barcelona: Herder, 2011), 65-87, 184-185.

14 Thomas Hobbes, Leviatán (Madrid: Editora Nacional, 1983), 221-226, 376.
} 
Esta afirmación permite el uso político del miedo. Los «fabricantes del miedo» construyen la «ideología del miedo», que actúa en la actual crisis económica. ${ }^{15}$ En la Edad Media, el miedo fabricado por la Iglesia fue facilitado, según Johan Huizinga, por la falta de voluntad «de hacer mejor y más dichoso el mundo». Para Erich Fromm, el miedo a la libertad dio como fruto el nazismo. Noam Chomsky ve la Guerra Fría como una construcción ideológica basada en la exageración de la amenaza soviética. El miedo a los «bárbaros», al otro, utilizado por organizaciones xenófobas, es, según Tzvetan Todorov, el que nos deshumaniza, nos convierte en «bárbaros». ${ }^{16}$

Antes de continuar, conviene observar, en primer lugar, que el miedo no puede abordarse según la perspectiva de la teoría sensitiva (William James), para la que lo determinante es la reacción fisiológica que provoca esa emoción, sino según la perspectiva cognitiva (Olbeth Hansberg), para la que las emociones tienen una estructura compleja de afectos y cogniciones o creencias: ${ }^{17}$ si el miedo en los animales es una reacción fisiológica ante una amenaza inmediata, el hombre puede prever el peligro. ${ }^{18}$ Según mi criterio, la gestión del miedo que hace la Iglesia tiene más que ver con lo cognitivo que con lo sensitivo. La religión ofrece una concepción del mundo, un universo simbólico que da seguridad. ${ }^{19}$ Pero las religiones, en segundo lugar, para ofrecer esa seguridad, recurren al miedo, sobre todo cuando se institucionalizan y son poder. El poder, en tercer lugar, no sólo provoca miedo en los que obedecen, sino en quien lo ejerce, pues se siente amenazado: ${ }^{20}$ en los manuales de Religión la Iglesia expresa sus propios temores.

\footnotetext{
15 Joaquín Estefanía, La economía del miedo (Barcelona: Galaxia Gutemberg-Círculo de Lectores, 2011), 15-32.

16 Johan Huizinga, El otoño de la Edad Media (Madrid: Alianza, 1978), 54; Erich Fromm, El miedo a la libertad (Barcelona-Buenos Aires: Paidós, 1980), 232-264; Noam Chomsky, El miedo a la democracia (Barcelona: Crítica, 1993), 11-35; Tzvetan Todorov, El miedo a los bárbaros (Barcelona: Galaxia Gutenberg-Círculo de Lectores, 2008), 18-39.

${ }_{17}$ Camps, El gobierno de las emociones, 27-28, 184-185.

${ }_{18}$ Marta Rodríguez Fouz, «El miedo nuclear. Amenazas y desvelos en un mundo globalmente atemorizado», en Sagrado/Profano. Nuevos desafíos al proyecto de la humanidad, eds. Josetxo Beriain e Ignacio Sánchez de la Yncera (Madrid: CIS, 2010), 271-272.

${ }^{19}$ Roberto Cipriani, Manual de sociología de la religión (Buenos Aires: Siglo XXI, 2001), 17-22.

${ }^{20}$ José Antonio Marina, La pasión del poder. Teoría y práctica de la dominación (Barcelona: Anagrama, 2008), 78, 137.
} 
El miedo, en cuarto lugar, no puede analizarse al margen del contexto. ${ }^{21}$ No puede entenderse la gestión del miedo que hacen los manuales de Religión al margen de la inseguridad que siente la Iglesia ante la secularización. Ésta puede entenderse como disgregación entre esferas seculares y norma religiosa, como declive de las creencias y prácticas religiosas y reclusión de la religión en el ámbito privado. ${ }^{22}$ Pero también como proceso por el que la religión se interesa por lo mundano. ${ }^{23}$ De hecho, la secularización (el interés por lo mundano) de las religiones es un fenómeno generalizado: forma parte de su repolitización como respuesta al reto de la modernidad. ${ }^{24} \mathrm{Si}$ es así, el miedo debe localizarse cada vez más en lugares profanos.

Por último, si tenemos en cuenta los contextos históricos, no es lo mismo la gestión del miedo que hace la Iglesia integrista anterior al Concilio Vaticano II (1962-1965) y la Iglesia posconciliar. Ni, después de esas fechas, la gestión del miedo que hace la «Iglesia líquida», aggiornata, que, más cercana a los valores del Vaticano II, pretende fluir para dialogar con la modernidad (cierto grado de pluralismo y de crítica interna, actitud de diálogo con el otro, ecumenismo,...) y controla la Conferencia Episcopal Española (CEE), máximo órgano de gobierno de la Iglesia católica en España, desde los años 70 hasta 1985, y la «Iglesia sólida» o neointegrista, aferrada a valores dogmáticos más fuertes (disciplina, coherencia doctrinal, intolerancia ante las «desviaciones»,...), que controla la CEE desde esa fecha. ${ }^{25}$

\section{LA GESTIÓN DEL MIEDO EN EL INTEGRISMO (ANTES DE 1965)}

Jean Delumeau distingue entre los «miedos espontáneos» (a la tempestad, la peste, la guerra,...), y los «miedos reflejos» (inducidos), gestionados por los «directores de conciencia de la colectividad»: miedos escatológicos

\footnotetext{
${ }^{21}$ Ana Aliende Urtasun, «La perspectiva social del miedo. Condiciones que lo originan y adaptación creativa del individuo», en Sagrado/Profano, 250-253.

22 José V. Casanova, Genealogías de la secularización (Barcelona: Anthropos, 2012), 23-34.

${ }^{23}$ Alfonso Pérez Agote, «Los límites de la secularización: hacia una versión analítica de la teoría», en Sagrado/Profano, 304-307.

${ }^{24}$ Ander Gurrutxaga, «La institución lobby: la religión en la política en contextos múltiples», en Religión y política en la sociedad actual, eds. Alfonso Pérez Agote y José Santiago (Madrid: Editorial Complutense-CIS, 2008), 67- 86.

${ }^{25}$ Sobre «Iglesia sólida» e «Iglesia líquida», Emilio Castillejo, La enseñanza de la Religión Católica en España desde la Transición (Madrid: La Catarata, 2012), 34-35.
} 
(Juicio Final, Demonio), miedo al otro (musulmán, judío, hereje), a la mujer, al desorden cultural, social o político, ...26

\section{La gestión de los miedos espontáneos}

En los documentos eclesiales, terremotos, guerras, enfermedades son consecuencia del pecado, del orgullo, de la desobediencia a la Iglesia,... que provocan la ira de Dios. ${ }^{27}$ Si la causa del mal está en el pecado, el remedio está en la penitencia, la indulgencia. Por eso, en épocas de sequía, por ejemplo, los boletines eclesiásticos hacen llamamientos a la oración ad petendam pluviam [para pedir que llueva]. ${ }^{28}$

Los manuales de Religión, sin descender a lo cotidiano, refuerzan la misma lógica al afirmar que Dios «es dueño y señor de todas las cosas y de todas las fuerzas y leyes de la naturaleza». ${ }^{29}$ Ese control permite el milagro, pero también el castigo: «Dios castiga con el diluvio a los hombres pervertidos»; 30 la iniquidad de Sodoma y Gomorra acarreó su destrucción; ${ }^{31}$ las pasiones desordenadas de Salomón trajeron la división del reino. ${ }^{32}$ La ira de Dios (y el miedo) sólo se aplaca con la obediencia.

\section{La gestión de los miedos inducidos}

El binomio Iglesia-miedo normalmente se asocia con la escatología: juicio final, infierno,... Los documentos eclesiales recuerdan la última venida y la necesidad de una vida piadosa para evitar el infierno. ${ }^{33}$ Los manuales de

\footnotetext{
26 Jean Delumeau, El miedo en Occidente (siglos XIV-XVIII). Una ciudad sitiada (Madrid: Taurus, 1989), 41-43.

27 Terremoto de Reggio y Mesina: Boletín Oficial Eclesiástico del Obispado de Pamplona, 1.106 (15 febrero 1909), 58-61. Inundaciones en Levante español: Boletín Oficial Eclesiástico del Obispado de Pamplona, 639 (21 septiembre 1891), 489-494. Gran Guerra: J. Abadal, «La providencia y la guerra actual», Razón y Fe, tomo 50 (1918): 483, 485. Cólera: Boletín Eclesiástico del Obispado de Calahorra y La Calzada (22 noviembre 1854), cuadernillo entre páginas 170 y 171.

${ }^{28}$ Boletín Eclesiástico del Obispado de Calahorra y La Calzada, 21 (15 noviembre 1856), 166; Boletín Oficial Eclesiástico del Obispado de Pamplona, 623 (4 marzo 1891), 97-98.

${ }^{29}$ Historia Sagrada. Tercer Grado (Bilbao: A.S.C.E.A., 1961), 123.

${ }^{30}$ Manual de Religión para niños (Valladolid-Palencia: Afrodisio Aguado, 1934), 24.

31 Historia Sagrada. Antiguo y Nuevo Testamento. Tercer Grado (Valladolid: Bruño, s.f.), 31-32.

32 Ricardo Díaz de Rueda, La Escuela de Instrucción Primaria (Valladolid: Imprenta de Cuesta y Compañía, 1850), 13. También Enciclopedia Escolar. Primer Grado (Barcelona: Luis Vives, 1934), 27.

33 Boletín Oficial Eclesiástico del Obispado de Pamplona, 1.332 (17 enero 1917), 17-32
} 
Religión inculcan miedo cuando narran el mito del pecado original, por el que el hombre quedó en "estado de naturaleza caída», sobre todo si acompañan el relato con la imagen de un ángel armado de espada que expulsa a Adán y Eva del Paraíso. ${ }^{34}$

Se induce el miedo cuando se expresan las consecuencias del pecado: «Si tienes diez pecados mortales, son diez cadenas las que te tienen sujeto al infierno. Si rompes nueve confesando sólo nueve [...] aún sigues atado al infierno con una cadena». ${ }^{35}$ Cuando se enseña al alumno la omnisciencia de Dios: «Dios existe y Dios te ve. De día. De noche. Ve tus pensamientos. Oye tus palabras. Nada se le esconde». ${ }^{36}$ Cuando, con imágenes del juicio final, se recuerda a los alumnos las palabras que pronunciará Jesús: «Apartaos de mi». ${ }^{37}$ Cuando se describen los «tormentos indecibles» del infierno con ayuda de ilustraciones en que aparece el cielo azul y el infierno rojo. ${ }^{38} \mathrm{La}$ fuerza sensitiva del miedo escatológico no prescinde de lo cognitivo: por la constante asociación entre pecado, orgullo y desobediencia; porque la Iglesia, además de miedo, ofrece esperanza, «la gloria y felicidad eterna». ${ }^{39}$ Con condiciones: "Si quieres ir al Cielo, obedece a la Iglesia» ${ }^{40}$. Extra ecclesiam nulla salus [fuera de la Iglesia no hay salvación].

Los documentos eclesiales inculcan también el miedo al otro no católico. Son una constante el antisemitismo y la descalificación del islam por razones teológicas e históricas: los moros usurparon «nuestro territorio», en referencia a la conquista de la Península Ibérica a partir del 711 d. C., realizaron «horribles desmanes»,... ${ }^{41} \mathrm{El}$ mismo miedo inculcan los manuales de Religión. Los bárbaros invadieron el Imperio cristiano matando, destruyendo,... ${ }^{42}$ Los judíos querían dominar el mundo, cometieron deicidio, per-

${ }^{34}$ Felipe Alcántara, Vida sobrenatural. Cursos de Religión para alumnos de Formación Profesional Industrial. Segundo Curso de aprendizaje (Barcelona: Librería Salesiana, 1963), 5-6.

35 Alcántara, Vida sobrenatural, 66.

${ }^{36}$ Enciclopedia. Primer Grado, 5.

${ }^{37}$ Manual de Religión para niños, 98-99.

${ }^{38}$ Manual de Religión para niños, 90.

39 Alcántara, Vida sobrenatural, 108.

40 Antonio Álvarez, Enciclopedia intuitiva, sintética y práctica. Primer Grado (Valladolid: Miñón, 1964), 52, 33.

${ }^{41}$ Pablo Hernández, «El mahometismo y la religión de los marroquíes», Razón y Fe, tomo 40 (1914): 447-461; J. Planella, «Judíos y moriscos españoles. Rectificación de un juicio erróneo», Razón y Fe, tomo 1 (1909): 496-506; Boletín Oficial Eclesiástico del Obispado de Pamplona, 1.116 [debería decir 1.117] (31 julio 1909): 251-252, y 1.835 (1 octubre 1936): 376.

42 Justo Pérez de Urbel, Historia Sagrada, Tercer Grado (Burgos: HSR, 1960), 212- 213. 
siguieron a los Apóstoles,... ${ }^{43} \mathrm{El}$ miedo al islam es teológico ( $« l o s$ placeres más repugnantes» de su paraíso) e histórico: el islam es un «azote» para la Iglesia; su expansión trajo «la corrupción de costumbres, el envilecimiento de la mujer, la esclavitud, la ignorancia y la ruina de los pueblos». ${ }^{44}$

Miedo al otro hereje. Los albigenses «sembraban la desolación». ${ }^{45}$ Los protestantes negaban los sacramentos, creían en la libre interpretación, ${ }^{46}$ provocaron revueltas y guerras de religión,... ${ }^{47} \mathrm{El}$ miedo a la herejía está muy presente también en los manuales de Religión, unánimes al describir el orgullo de Lutero, la intransigencia de Calvino, las consecuencias nefastas de la Reforma (guerras de religión, alteración del orden social) y el libre examen, que abre paso al filosofismo y el racionalismo. ${ }^{48} \mathrm{El}$ protestantismo queda incluido así en la denigrada modernidad.

La Iglesia tiene razones para sentir lo que José Antonio Marina llama «miedo al hundimiento de la cultura» que supone la modernidad, ${ }^{49}$ con la que la Iglesia deja de ser la institución de la sociedad para convertirse en un grupo social específico. ${ }^{50}$ La Ilustración comprende que el hombre puede cambiar el mundo. ${ }^{51}$ La Iglesia teme esa autonomía del hombre. Los antiguos, antes de hablar del logos, habían inventado a Prometeo, que desobedece a Zeus y da el fuego a los hombres. ${ }^{52}$ Para la filosofía cristiana, en cambio, Dios es armonía, el hombre, ruptura del orden creado; sólo sometiéndose a la ley divina el hombre encontrará la paz. ${ }^{53}$ El pensamiento eclesial hace genealogía de la deriva catastrófica del pensamiento: Lutero

\footnotetext{
${ }^{43}$ Díaz de Rueda, La Escuela, 31; Antonio Álvarez, Enciclopedia intuitiva, sintética, práctica (Ajustada al Cuestionario Oficial). Grado de Iniciación Profesional (Valladolid: Miñón, 1971), 130-131; Manual de Religión para niños, 167.

${ }^{44}$ Pérez de Urbel, Historia Sagrada, 216-217. También Historia Sagrada. Primer Grado (Barcelona: FTD, 1926), 70-71.

45 Boletín Oficial Eclesiástico del Obispado de Pamplona, 640 (8 octubre 1891): 511-513.

46 Boletín Oficial Eclesiástico del Obispado de Pamplona, 192 (28 enero 1870): 41.

47 Boletín Eclesiástico del Obispado de Calahorra y La Calzada, 13 (5 julio 1873): 100-101.

${ }^{48}$ Historia Sagrada. Segundo Grado (Zaragoza: Luis Vives, 1951): 259-270.

49 Marina, Anatomía del miedo, 122-123.

${ }^{50}$ Rafael Díaz Salazar, «Institución religiosa y democracia en España», en Religión y política, 129-147.

${ }^{51}$ Philipp Blom, Encyclopédie. El triunfo de la razón en tiempos irracionales (Barcelona: Anagrama, 2007); Anthony Pagdem, La Ilustración y sus enemigos (Barcelona: Península, 2002), 23-37.

52 Hans Blumenberg, Trabajo sobre el mito (Barcelona: Paidós, 2003), 35-39, 55-61.

${ }_{53}$ J. Iturrioz, «El hombre en crisis frente al cosmos. En torno al mensaje pontificio de Navidad 1957», Razón y Fe, tomo 157 (1958), 117-130.
} 
(libre interpretación), Descartes (cuestionamiento de los dogmas), Proudhon (descomposición del edificio social). ${ }^{54}$

La expresión más acabada de ese miedo es la Encíclica Quanta Cura de Pío IX, que contiene el Syllabus donde se condena el laicismo, el liberalismo, el socialismo, la masonería y el racionalismo o idea de que el hombre con sólo su razón puede alcanzar la verdad. La Iglesia, como sociedad perfecta, reclama su derecho a condicionar la vida civil: no puede transigir «con el progreso, el liberalismo y la civilización moderna». ${ }^{55}$ Los documentos eclesiales advierten una y otra vez sobre los peligros de la civilización moderna: libertinaje, calamidades, sacrilegios, comunismo. ${ }^{56}$ Sobre el peligro que supone la ciencia histórica, si cuestiona los bienes temporales de la Iglesia. ${ }^{57}$ Sobre el peligro de la fisiología, la medicina, la sicología y la ética, si sostienen el materialismo. ${ }^{58}$ Para España, los daños todavía son más perversos: el catolicismo «es la base primordial y fundamental de la sociedad española» (es la idea esencial del nacionalcatolicismo), por tanto los que difunden los valores modernos son reos «de lesa divinidad y de lesa nación». ${ }^{59}$ Temor también a la que la Iglesia considera la principal difusora del pensamiento disolvente, la masonería. ${ }^{60}$

Es necesario, por tanto, restaurar la filosofía cristiana, la escolástica, síntesis perfecta de razón y fe. ${ }^{61}$ Tomás de Aquino es para la Iglesia el referente, como lo es Menéndez Pelayo (1856-1912), principal representante del pensamiento nacional-católico. ${ }^{62}$ Se reivindica también la «unidad católica» frente a la «libertad del error», que así llaman al pluralismo. ${ }^{63}$ Se trata del

\footnotetext{
${ }^{54}$ Boletín Eclesiástico del Obispado de Calahorra y La Calzada, 22 (30 noviembre 1858 [¿1859?]), 69-171.

55 Boletín Oficial Eclesiástico del Obispado de Pamplona, 46 (25 enero 1865), 15-31.

${ }^{56}$ Boletín Oficial Eclesiástico del Obispado de Pamplona , 48 (5 febrero 1865), 41-55.

${ }^{57}$ Boletín Oficial Eclesiástico del Obispado de Pamplona, 64 (15 setiembre 1865), 233-247; 66 (30 setiembre 1865), 261-271; y 68 (16 octubre 1865), 281-291.

${ }^{58}$ Boletín Oficial Eclesiástico del Obispado de Pamplona, 7 (1 abril 1943), 101-105, y 8 (15 abril 1943), 117-118.

${ }^{59}$ Boletín Oficial Eclesiástico del Obispado de Pamplona 44 (24 diciembre 1864), 397-406, y 21 (10 febrero 1864), 172-178.

${ }^{60}$ N. Noguer, «La educación naturalista. Sus padres y fautores», Razón y Fe, tomo 35 (1913), 57-70. También: Ricardo García Villoslada, «San Antonio María Claret y la francmasonería», Razón y Fe, tomo 165 (1962), 163-174.

${ }^{61}$ Boletín Oficial Eclesiástico del Obispado de Pamplona, 339 (3 noviembre 1879), 321-349.

62 Rafael Hornedo, «La conciencia española de Menéndez Pelayo», Razón y Fe, tomo 139 (1949), 425-426.

63 Ángel M. ${ }^{a}$ de Arcos, «La libertad del error», Razón y Fe, tomo 13 (1905), 207-224.
} 
miedo a la libertad. La unidad católica exige, además, defender la prensa católica frente a «la prensa impía», ${ }^{64}$ respaldar su prohibición, ${ }^{65}$ negar la libertad de cátedra: «toda la enseñanza debe ser católica». ${ }^{66}$

Los manuales de Religión también interpretan la modernidad como «catástrofe»: el Renacimiento corrompió las costumbres; las ideas de los «tiempos modernos» acarrean el "odio al catolicismo», el desorden social, el laicismo, "que suprime la religión en el orden cívico y social», el liberalismo, cuyo fruto emponzoñado es el socialismo y el comunismo. ${ }^{67} \mathrm{Un}$ "sistema que pretende que el hombre es esencialmente independiente de toda autoridad sobrenatural». ${ }^{68}$ El freno contra los «enemigos» de la Iglesia sigue siendo el Syllabus, Menéndez Pelayo... ${ }^{69}$

La inquietud de la Iglesia ante los avances científicos también encuentra eco en los manuales de Religión. Dado que la Iglesia hace todavía una lectura literal de la Biblia, se pretende hacer creer a los alumnos que la ciencia no hace sino comprobar las verdades bíblicas: el orden en que Moisés cita la creación de los animales «coincide, casi exactamente, con los descubrimientos que la ciencia ha hecho». ${ }^{70}$

En los documentos eclesiales la Iglesia teme el desmoronamiento de valores sociales y morales. Exhorta al olvido de «los placeres del cuerpo», origen de todos los males: crueldad, tiranía, escándalos... ${ }^{71}$ Pide "cerrar la puerta de los sentidos». ${ }^{72}$ Su objetivo básico es lo que Michel Foucault llamó el control de los cuerpos. ${ }^{73}$ De ahí que se alerte contra los espectáculos inmorales, ${ }^{74}$ se exalte la Cuaresma..., ${ }^{75}$ que algunos curas párrocos se congratulen de la

\footnotetext{
${ }^{64}$ Boletín Oficial Eclesiástico del Obispado de Pamplona, 1.760 (24 junio 1933), 205.

${ }^{65}$ Boletín Oficial Eclesiástico del Obispado de Pamplona, 22 (25 febrero 1864), 186-187.

${ }^{66}$ Boletín Oficial Eclesiástico del Obispado de Pamplona, 1.839 (1 diciembre 1936), 443-451.

${ }^{67}$ Pérez de Urbel, Historia Sagrada, 220, 226-229.

${ }^{68}$ Manual del Católico Militante (San Sebastián: Seminario Católico La Cruz, 1930), 27-31.

${ }^{69}$ Historia Sagrada. Segundo Grado, 276-277.

70 Álvarez, Enciclopedia. Grado de Iniciación Profesional, 70.

${ }^{71}$ Boletín Oficial Eclesiástico del Obispado de Pamplona, 622 (10 febrero 1891): 87.

72 Boletín Oficial Eclesiástico del Obispado de Pamplona, 346 (4 febrero 1880), 33-47.

${ }^{73}$ Michel Foucault, Microfísica del poder (Madrid: La Piqueta, 1992), 148-157, y Un diálogo sobre el poder (Madrid: Alianza, 1988), 128.

${ }^{74}$ Eustaquio Miqueleiz, S. J., La cruzada contra los espectáculos inmorales, (Bilbao: Ochoa, Olaso y Compañía, 1916).

${ }^{75}$ Boletín Eclesiástico del Obispado de Calahorra y La Calzada, 6 (14 marzo 1874): 45-47.
} 
«docilidad, sumisión y respeto» con que los sencillos agricultores acuden a la liturgia. ${ }^{76} \mathrm{El}$ miedo al cuerpo va asociado al miedo a la mujer. Se ataca el «feminismo sin Dios», que proclama «el amor libre, la adoración de la carne y la materia» y conduce a la mujer a descabellados proyectos de emancipación e igualdad. ${ }^{77}$ Se recomienda a la mujer modestia, decencia y pudor, frente a la vanidad, el lujo, la moda en que muchas veces cae «el sexo débil». ${ }^{78}$ El matrimonio cristiano es «el valladar más potente» contra el neopaganismo ${ }^{79}$ y los «vicios feminiles» (vanidad, ociosidad, gastos excesivos). ${ }^{80}$ La Iglesia exalta modelos como Santa Juana Francisca de Chantal, «excelente ama de casa», que «no manifestó nunca un deseo contrario a los de su marido». ${ }^{81}$

El mismo miedo al cuerpo reflejan los manuales de Religión. Contraponen lujuria $\mathrm{o}$ "apetito desordenado ${ }^{82} \mathrm{y}$ castidad o dominio de «los placeres ilícitos de la carne». ${ }^{83}$ Frente al pecado sólo cabe la penitencia, el sentimiento de culpa y la «excitación del dolor» ante la imagen de Cristo crucificado: «Y piensa [se aconseja al alumno]: Ésta es la obra de mi pecado». ${ }^{84}$ No pueden separarse, por tanto, los elementos afectivos (el sentir) y cognitivos (el pensar) del relato. No falta tampoco la referencia a Eva que, por orgullo y curiosidad, fue la primera que «se dejó persuadir». ${ }^{85} \mathrm{El}$ reverso de Eva es, por supuesto, María. ${ }^{86}$

Pero la Iglesia no teme sólo el desmoronamiento de valores morales, sino también el del orden social en sí: «La sociedad está en peligro de muerte». ${ }^{87}$ La Iglesia, que teme el presente, añora el modelo del Antiguo Régimen

\footnotetext{
76 Boletín Oficial Eclesiástico del Obispado de Pamplona, 57 (26 junio 1865): 178-179.

77 Julio Alarcón y Meléndez, «El feminismo sin Dios», Razón y Fe, tomo 3 (1902), 457-474.

78 Boletín Oficial Eclesiástico del Obispado de Pamplona, 139 (25 febrero 1869): 101.

79 Boletín Oficial del Obispado de Pamplona, 1 (1 enero 1945): 12.

${ }^{80}$ Confederación Católica Nacional de Padres de Familia, Anillo de boda (Bilbao: Eléxpuru Hermanos, 1939), 21-22.

${ }^{81}$ La Santa de los veinte años. Novena en honor a Santa Juana Francisca de Chantal (Vitoria: Imprenta Moderna, 1941). Sin paginar.

82 Alcántara, Vida sobrenatural, 100.

83 José Zahonero, Miguel Martín, Moral y doctrina social de la Iglesia. Formación religiosa. Quinto Curso de Bachillerato Laboral (Alcoy: Marfil, 1967), 101-102.

84 Alcántara, Vida sobrenatural, 61, 85-86, 102.

85 Pérez de Urbel, Historia Sagrada, 14.

86 Zahonero y Martín, Moral y doctrina..., 101-103.

87 Boletín Eclesiástico del Obispado de Calahorra y La Calzada, 6 (24 febrero 1872): 43.
} 
(religión, paz social), alterado por el orgullo, la codicia, la sensualidad, el progreso con que «patronos y obreros se han ido despeñando de precipicio en precipicio hasta los abismos de la anarquía». ${ }^{88}$ Para la Iglesia forman parte del mismo proceso revolucionario el liberalismo, el anarquismo, el bolchevismo ${ }^{89}$ y la socialdemocracia, que no rechaza la lucha de clases ni la abolición de la propiedad. ${ }^{90}$ La alternativa es la encíclica Rerum Novarum (1891), que tiene como modelo los gremios medievales, expresa el temor a cualquier utopía y cambio social («sufrir y padecer es la suerte del hombre»), defiende la propiedad privada, indiferente a la virtud y, desde una perspectiva organicista, indica las obligaciones de los «amos» (salario justo) y de los obreros. ${ }^{91}$ Concordia que no excluye la justificación del «saludable rigor» frente a huelgas, sindicatos, prensa... ${ }^{92}$

El modelo de los manuales de Religión son también los gremios medievales, «el elemento de mayor equilibrio social que registra la historia», que se desmorona con el individualismo económico, el socialismo y el anarquismo. El socialismo y el comunismo, que denigran el trabajo por considerarlo mal irremediable (olvidando que el mito de la expulsión del Paraíso parte de presupuestos semejantes), son considerados hijos del liberalismo, que considera el trabajo una mercancía. ${ }^{93}$ Se completa así el Eje del Mal: humanismo-protestantismo-Ilustración-liberalismo-socialismo-comunismo-anarquismo-revolución.

Los manuales de Religión, fieles al paternalismo eclesial, recuerdan las obligaciones de los «criados» (obediencia, respeto "por su dignidad de representantes de Dios») y de los «amos» (retribución adecuada, formación moral). ${ }^{94}$ La verdadera igualdad consiste en la creación de los hombres «sin

\footnotetext{
${ }^{88}$ Narciso Noguer, «En busca de la armonía industrial. I», Razón y Fe, tomo 5 (1903), 22.

${ }^{89}$ V. Minteguiaga, "La propaganda anarquista ante el derecho», Razón y Fe, tomo 13 (1905): 32-45; José $\mathrm{M}^{\mathrm{a}}$ Llanos, «Estilo de la juventud nueva», Razón y Fe, tomo 112 (1937); Joaquín Azpiazu, «Ideología bolchevique», Razón y Fe, tomo 59 (1921): 426-441; «Discurso del Padre Santo a veinte mil obreros el día de Pentecostés», Boletín Oficial del Obispado de Pamplona, 13 (1 julio 1943): 13.

90 Pío XI, «Sobre la Cuestión Social», Boletín Oficial Eclesiástico del Obispado de Pamplona, 1.713 (24 junio 1931): 277-281.

91 León XIII, «Encíclica Rerum Novarum», Boletín Oficial Eclesiástico del Obispado de Pamplona, 631 (6 julio 1891), 297-336

92 Venancio Minteguiaga, «La huelga ante la moral y el derecho», Razón y Fe, tomo 3 (1902): 96.

93 Zahonero y Martín, Moral y doctrina social, 187, 219.

94 Zahonero y Martín, Moral y doctrina social, 84.
} 
distinción alguna». ${ }^{95}$ Legitimada la propiedad privada y la riqueza, indiferentes a la salvación, la Iglesia recomienda «emplear cristianamente el exceso de riqueza en limosnas, obras sociales y benéficas, etc.». ${ }^{96} \mathrm{~A}$ los ricos les recuerda la parábola del rico epulón, que enseña «que las riquezas, si no se usan bien, fácilmente llevan al hombre a la perdición». ${ }^{97} \mathrm{~A}$ los pobres, las bienaventuranzas y la mansedumbre, con que dominarán la ira, la rebeldía... ${ }^{98}$ No rechaza la Iglesia los sindicatos, siempre y cuando «se constituyan y rijan por los principios de la fe y moral cristianas». ${ }^{99}$

La Iglesia teme también el desmoronamiento de la política. No entiende el laicismo como lo que es: separación de la Iglesia y el Estado, y neutralidad de éste en materia religiosa. ${ }^{100}$ Prefiere el catastrofismo: las «terribles secuelas para la sociedad» de un «Estado sin religión» o del principio de que la autoridad emana «únicamente del pueblo». ${ }^{101}$ Los manuales también recuerdan que el laicismo es «la peste de nuestros tiempos». Que no hay conciliación posible entre catolicismo y liberalismo: que los liberales católicos son «más peligrosos y funestos que los enemigos declarados, porque con su apariencia de probidad seducen a los incautos». Que con el liberalismo los gobiernos españoles se apartaron de «la Unidad Católica», lesionando «los derechos de la verdad y de la religión católica». El nacionalcatolicismo, la identidad católica de España, es reforzado con la idea de que el Estado es inferior a la Iglesia en dignidad y, por tanto, debe reconocer su autoridad en materia moral y religiosa. ${ }^{102}$

El miedo al desmoronamiento cultural, social y político que siente la Iglesia ante la modernidad es, sobre todo, miedo a la pérdida de posición, influencia social y medios de subsistencia. Por eso Pío IX afirma que el Estado liberal pretende expulsar a la Iglesia del seno de las instituciones civiles y de la escuela. ${ }^{103}$ Los boletines eclesiásticos se hacen eco de la amarga pér-

\footnotetext{
95 Manual del Católico, 48.

96 Alcántara, Vida sobrenatural, 99.

97 A.S.C.E.A., Historia Sagrada, 152, 229. También: FTD, Historia Sagrada, 59.

98 Alcántara, Vida sobrenatural, 106-107.

99 Manual del Católico, 48.

100 Pérez Agote y Santiago (eds.), Religión y política, 11 (Introducción).

101 Boletín Oficial Eclesiástico del Obispado de Pamplona, 1.716 (1 septiembre 1931), 367.

102 Manual del Católico, 15-17, 22-23, 33.

103 Boletín Oficial Eclesiástico del Obispado de Pamplona, 36 (10 septiembre 1864).
} 
dida de los Estados Pontificios, ${ }^{104}$ así como del despojo de los bienes de la Iglesia española por las desamortizaciones de Mendizábal (1836) y Madoz (1855). ${ }^{105}$ Miedo por el proyecto de la II República española (1931-1936) de suprimir el presupuesto de culto y clero, que sumirá a la Iglesia «en la miseria». ${ }^{106}$ Los manuales recuerdan que la enseñanza debe ser católica, que la Iglesia no puede ser despojada de sus bienes «sin injusticia por ser una sociedad humana, y sin sacrilegio, por ser una sociedad sobrenatural». ${ }^{107}$ Con dramatismo recuerdan «la expoliación» de los bienes eclesiásticos, en referencia a las citadas desamortizaciones. ${ }^{108}$

En esencia, la Iglesia integrista inculca el miedo al pecado, al Juicio Final y al infierno: esas imágenes terroríficas otorgan más relevancia a los aspectos sensitivos del miedo, sin olvidar los cognitivos: la obediencia a la Iglesia garantiza la salvación. El miedo a la ira de un Dios que controla la naturaleza: sólo la obediencia puede aplacar el miedo a las inundaciones, las sequías, la enfermedad, la guerra. Y el miedo a la secularización y el laicismo, que amenazan su supervivencia. La religión desde el principio ha sido lenguaje de orden que legitima y sacraliza el poder, una teología política. ${ }^{109}$ La religión es teología política (sacrum nexum, nexo sagrado), entre otras cosas, porque el miedo que inculca va más allá de lo sagrado e invade lo profano.

\section{LA GESTIÓN DEL MIEDO TRAS EL VATICANO II}

Con el Concilio Vaticano II (1962-1965) la Iglesia no se recluye en el ámbito privado: surge una suerte de catolicismo público para defender la vida tradicional o el «bien común» frente al individualismo o al socialismo. ${ }^{110}$ Continúa, por tanto, el interés por lo mundano (secularización, repolitización). Tras el Vaticano II y el restablecimiento de la democracia en España después de la muerte de Franco en 1975, dado que el universo simbólico de

\footnotetext{
104 Boletín Oficial Eclesiástico del Obispado de Pamplona, 221 (13 junio 1871): 161-164.

105 Boletín Eclesiástico del Obispado de Calahorra y La Calzada, 16 (31 agosto 1857): 128.

106 Boletín Oficial Eclesiástico del Obispado de Pamplona, 1721 (15 noviembre 1931): 433-436.

107 Manual del Católico, 22.

108 Salvador Egea et al., Experiencia y Fe, 1. ${ }^{\circ}$ BUP (Madrid: Bruño, 1974), 96.

109 Patxi Lanceros, Orden sagrado, santa violencia. Teo-tecnologías del poder (Madrid: Abada, 2014), 74-125.

110 Casanova, Genealogías de la secularización, 164-167.
} 
la Iglesia no tiene por qué ser compartido por otras asignaturas (al contrario que en el sistema educativo confesional del franquismo en que los valores eclesiales contaminan todo el currículo escolar), la Iglesia se ve obligada a ofrecer su visión del mundo, a competir con otras cosmovisiones. ${ }^{111}$ Por eso la jerarquía eclesial subraya en 1971 la conveniencia de que los seminaristas estudien el ateísmo, el marxismo..., y tengan armas doctrinales para dialogar con un mundo secularizado. ${ }^{112}$ Ese cambio afecta profundamente a la gestión del miedo.

En principio, con el Vaticano II la Iglesia aligera el miedo a la ciencia, al pluralismo, al presente, al otro... e insiste más en la esperanza. El Concilio proclama la «autonomía» de la ciencia para «alcanzar la realidad inteligible», la confianza en el "progreso altamente beneficioso para el hombre». Asume principios liberales: «igualdad esencial entre todos los hombres», «responsabilidad y participación en los esfuerzos comunes», elección de los gobernantes. No teme el presente: no añora los gremios; asume el capitalismo moderno, añadiendo dos notas antimarxistas: el capital tiende a «diversificarse» (negación de la ley de concentración del capital); los conflictos deben resolverse de forma pacífica (negación de la lucha de clases). ${ }^{113} \mathrm{El}$ Vaticano II, por último, parece perder el miedo al otro: habla de «mutua comprensión» entre la Iglesia, el islam, los judíos... ${ }^{114}$

Los manuales de Religión también reducen el miedo en favor de la esperanza. Para la editorial SM, «en la base del sentimiento religioso está la admiración por Dios y la divinidad, y no el temor o el deseo de utilizar la divinidad en beneficio propio como ocurre con la magia y la superstición». Guías del profesor como la de la editorial Anaya recomiendan explicar a los alumnos que «la esperanza de una vida cada vez más humana» entra en el «proyecto de Dios». ${ }^{115}$ Pero ello no significa que desaparezcan los miedos del pasado: incluso aparecen miedos nuevos.

\footnotetext{
111 Castillejo, La enseñanza de la Religión, 23-28.

112 Boletín Oficial de la Diócesis de Pamplona y Tudela, 3 (marzo 1971): 143-147.

113 «Gaudium et Spes», en Documentos del Vaticano II. Constituciones. Decretos. Declaraciones (Madrid: BAC, 1986), 208-209, 211, 224-225, 229-230, 258, 263, 271-272, 279.

114 «Nostra Aetate», «Lumen Gentium», «Unitatis redintegratio», «Dignitatis humanae», en Documentos del Vaticano II, 614- 615, 52, 467, 535, 579.

115 J. Cortés, S. Forcada y G. Castaño, Religión católica, 4. ${ }^{\circ}$ ESO (Madrid: SM, 2003), 17; Equipo Pedagógico Cultura y Religión, Religión católica. Guía del Educador, 2. ${ }^{\circ}$ EGB (Madrid: Anaya, 1981), 12-14.
} 


\section{Los miedos naturales}

La Iglesia integrista manipuló los miedos naturales. Ahora, sin embargo, algún manual echa reprimendas a los que acuden a Dios sólo cuando tienen miedo a la muerte, a un peligro... ${ }^{116}$ En cualquier caso, el Dios posterior al Vaticano II ejerce un menor control sobre la naturaleza: la ciencia (la geología, la meteorología, la historia...) ha encontrado (y popularizado) explicaciones mejores del desastre. También la gente es consciente de que un accidente nuclear es achacable al hombre, no a un castigo divino. ${ }^{117}$

En los manuales, los diluvios y pestes dejan de ser resultado de la ira de Dios: Yahvé inspira menos temor: Joseph S. Nye hablaría de soft power. Sólo algún manual neointegrista hace afirmaciones que ahora resultan heteróclitas: «Dios quiso enviar el diluvio universal para aniquilar a los hombres, excepto Noé y su familia» (Casals, $2{ }^{\circ}$ ESO). Sólo algunos textos como Casals (1. ${ }^{\circ}$ ESO) vinculan los pecados de Salomón con la división del reino, la deportación a Babilonia... Pero Edebé (1. ${ }^{\circ}$ ESO) no presenta a un Dios vengativo, sino a un Dios «disgustado» por los pecados de David (Betsabée, Urías), que envía al profeta Natán y consigue que se arrepienta. Edebé (Primaria) habla de un Dios que ofrece «la amistad» a su pueblo y que, «a pesar de las infidelidades», envía a los profetas para recordar la Alianza. El poder de Jesús sobre la naturaleza también se debilita. Sólo editoriales neointegristas como Magisterio señalan que Jesús hace milagros para mostrar «su poder divino» sobre la enfermedad y la muerte. Para la mayoría —es el caso de Everest-, Jesús no hace milagros para mostrar su poder sobre la naturaleza, sino porque estaba atento a los problemas de la gente. ${ }^{118}$

\section{Los miedos escatológicos}

La Iglesia, aunque ahora rechaza una imagen grotesca del demonio (que los manuales de Religión contribuyeron a difundir), sigue insistiendo en el miedo al demonio y en el combate contra el mismo hasta la «segunda

\footnotetext{
116 J. Aldazábal, J. Mascaró y J. A Montull, Religión, 1. ํ Bachillerato (Barcelona: Edebé, 1998$), 126$.

117 Rodríguez Fouz, «El miedo nuclear», 272-273.

118 J. Martínez García, Kairós. Religión Católica, 2. ${ }^{\circ}$ ESO (Barcelona: Casals, 2004), 41; P. de la Herrán y J. Martínez, Religión católica, $1 .^{\circ}$ ESO (Barcelona: Magisterio-Casals, 2003), 53-56; A. Yunyent, E. Andrés y M. Pueyo, Religión católica, $1 .^{\circ}$ ESO (Barcelona: Edebé, 2000), 73-74; Edebé, Religión católica, $6 .^{\circ}$ Primaria (Barcelona: Edebé, 1995), 26; J. García Inza y P. de la Herrán, Fe y vida. Jesucristo es el camino, $7 .^{\circ}$ EGB (Madrid: Magisterio, 1984), 33; Equipo Aldebarán, Religión. 4. Primaria (León: Everest, 1996$), 55$.
} 
venida» ${ }^{119}$. Dado que la lucha continúa, los obispos, al ser consagrados, prometen no prestar a los que yerren «favor alguno» ${ }^{120} \mathrm{y}$ piden a los párrocos que estén «alerta» con la difusión de ideas heréticas. ${ }^{121}$ La Sagrada Congregación para la Doctrina de la Fe censura las «afirmaciones peligrosas» de ciertas publicaciones: es el miedo a la libertad. ${ }^{122}$

Especialmente los manuales más aggiornati aligeran el terror del Juicio Final. Fenómeno paralelo a la falta de credibilidad y al hundimiento sociológico de la creencia en el infierno, que ha conducido a una auténtica «conspiración de silencio» sobre el mismo en los medios católicos. ${ }^{123}$ Santillana habla simplemente de separación de «justos y pecadores». Para SM, el Juicio Final significará la «restauración del universo», en que «brillarán la paz, la justicia y la felicidad más completas». El Juicio Final ya no se asocia al miedo, sino a la esperanza, una esperanza escatológica, aunque a veces envuelta en un lenguaje milenarista: «Estamos en marcha hacia la progresiva liberación del hombre, que dependerá de todos nosotros. La humanidad es una gran empresa en que todos estamos comprometidos» (Bruño). ${ }^{124}$

El miedo al pecado se mantiene. Pero la Iglesia líquida amplía su semántica (el pecado es el miedo, la intolerancia, la insolidaridad con el diferente,...), e insiste más en la esperanza: el cristiano debe ser libre, «esperanzado». ${ }^{125}$ Redemptor Hominis de Juan Pablo II, buen representante de la Iglesia sólida, sin olvidar las injusticias sociales, espiritualiza el mensaje: el objetivo es salvar al hombre, que no puede olvidar la «carga amonestadora» del Juicio Final, del materialismo. ${ }^{126}$ La CEE en 2007 también habla del aliento que da la Cruz frente a la desesperanza en un mundo dominado por el laicismo, el ateísmo. ${ }^{127}$

\footnotetext{
119 Boletín Oficial de la Diócesis de Pamplona y Tudela, 3 (1 marzo 1965): 1.953-1.954.

${ }^{120}$ Consagración Episcopal del Excelentísimo y Reverendísimo Señor Doctor D. Ángel Suquía Goicoechea, Obispo de Almería (Vitoria: Seminario Diocesano de Vitoria, 1966), 16.

121 Boletín Oficial de las Diócesis de Pamplona y Tudela, 2 (1 abril 1965): 57-58.

122 Boletín Oficial de las Diócesis de Pamplona y Tudela, 5 (mayo 1979), 237.

123 Georges Minois, Historia de los infiernos (Barcelona: Paidós, 2005), 457-460.

124 E. Piédrola y F. Ibáñez, Religión, 6. ${ }^{\circ}$ EGB (Madrid: Santillana, 1980), 62; G. Castaño, J. Cortés y M.A. Cortés, Betel. Religión Católica, $4 .^{\circ}$ ESO (Madrid: SM, 1998), 138; Salvador Egea et al., Experiencia, (Bruño), 39.

125 Boletín Oficial de las Diócesis de Pamplona y Tudela, 3 (marzo 1979): 85-93.

126 Boletín Oficial de las Diócesis de Pamplona y Tudela, 4 (abril 1979): 136-157.

127 Boletín Oficial de las Diócesis de Pamplona y Tudela, (enero 2007): 62.
} 
Los manuales inculcan también el miedo al «mundo», que para la editorial Larrauri es el olvido de la capacidad de sacrificio, los apetitos desordenados...; el miedo al pecado, pero recordando, más que el castigo, la esperanza de salvación. Para la editorial Luis Vives, «Cristo, nos librará del pecado, devolviéndonos la Vida Divina»; para la editorial Everest, Cristo guía al hombre «al encuentro de lo infinito». ${ }^{128}$

El pecado sigue siendo el orgullo, la soberbia, el deseo de vivir al margen de Dios (SM). Las editoriales neointegristas (Casals) insisten en el pesimismo antropológico (la inclinación del hombre al mal) y, dada la tendencia de la religión a repolitizarse, amplían la gama de consecuencias: «las guerras, los odios, el terrorismo, los homicidios, las injusticias sociales, la violencia doméstica, la marginación y la muerte de tantos inocentes». El aggiornamento coloca en primer plano los efectos sociales del pecado: para Santillana, el pecado es ruptura con los demás (injusticia, conflictos, miseria, analfabetismo,...), con la naturaleza (monopolio de los recursos por unos pocos), y con Dios, al que el hombre considera su rival. ${ }^{129}$ El infierno ya no está en el núcleo de la Tierra, sino en la corteza terrestre: son los efectos de la secularización.

\section{El miedo al otro}

El miedo al otro se mueve en los documentos eclesiales entre el ecumenismo y el convencimiento de la superioridad del cristianismo: para Juan Pablo II evangelizar no es «imponer», sino "proponer» «la Verdad cristiana». ${ }^{130}$ Benedicto XVI ante la Fundación para la Investigación y el Diálogo Interreligioso e Intercultural propone «discernir los valores capaces de iluminar a los hombres y mujeres de todos los pueblos de la tierra, independientemente de su cultura y religión», ${ }^{131}$ pero en la encíclica Spe Salvi afirma que sólo el Creador puede establecer unos valores fundados en la

\footnotetext{
128 Pedro M. Zalbide, El adolescente y el mundo. Tercer Curso de Formación religiosa (Bilbao: Larrauri, 1990), 21; Á. Álvarez Alfaro et al., El paso de Dios. Área de Formación Religiosa, 6. ${ }^{\circ}$ EGB (Zaragoza, Luis Vives, 1973), 35; Equipo Aldebarán, Religión, 2. ${ }^{\circ}$ Bachillerato (León: Everest, 1998), 94.

129 J. Cortés, M. A. Cortés y S. Forcada, Religión católica, 2. ${ }^{\circ}$ ESO (Madrid: SM, 2008), 40; P. de la Herrán y A. Fernández, Kerigma. Religión católica, Bachillerato (Barcelona: Casals, 2009), 73; Santillana, Religión. 2. ${ }^{\circ}$ BUP (Madrid: Santillana, 1978), 132-134.

${ }_{130}$ Boletín Oficial de las Diócesis de Pamplona y Tudela, 9 (septiembre 1979): 355-357.

131 Boletín Oficial de las Diócesis de Pamplona y Tudela (febrero 2007): 306-307.
} 
esencia de la humanidad inviolables e inmutables. ${ }^{132}$ Su mensaje a los musulmanes con ocasión del Ramadán habla de colaboración entre cristianos y musulmanes, y cita el terrorismo (islámico): recordar todas las violencias sería la manera más sincera de empezar ese diálogo interreligioso. ${ }^{133} \mathrm{El}$ cardenal Martino, para aclarar los polémicos comentarios de Benedicto XVI en la Universidad de Ratisbona, insiste en que ninguna religión tiene nada que temer del catolicismo: «el verdadero enemigo de todas, el más insidioso y solapado, es el paradigma ético-cultural de una razón sin Dios», «fascinado por sus éxitos científicos y técnicos». ${ }^{134}$ Es el miedo a los «sin Dios».

Los manuales reflejan estas contradicciones. Las editoriales neointegristas también hablan de «respeto» hacia las demás religiones, pero señalando el verdadero camino, «la redención realizada por Jesucristo». ${ }^{135}$ Todas las editoriales, dada su pretensión de dar una visión positiva de las religiones en su conjunto («la religión es un espacio para el encuentro», dice SM), deben hacer abstracción de los conflictos históricos y olvidar el papel real de la religión en los mismos. Verbo Divino propone «olvidar» los conflictos e insistir «en lo que nos une». ${ }^{136}$

A pesar del respeto por la espiritualidad de las religiones orientales, Cénlit asocia el hinduismo a «supercherías» (reencarnación), resignación, engaño de los brahmanes a «la gente sencilla», como si el cristianismo no reprodujera fenómenos semejantes. EDICE parece preocuparse por su expansión en Occidente. ${ }^{137}$ Desaparece el antisemitismo y la referencia al deicidio, pero no la referencia a las «interpretaciones tendenciosas» que hace la religión judía de la Biblia (Casals) o, en los aggiornati, al «radicalismo ortodoxo» (Edebé). ${ }^{138}$ En ningún manual la Iglesia y el clero aparecen como protagonistas de pogromos y expulsiones de que los judíos fueron

\footnotetext{
132 Steven Lukes, Relativismo moral (Madrid: Paidós, 2011), 165.

133 Boletín Oficial de las Diócesis de Pamplona y Tudela (noviembre 2006): 1.424-1.426.

134 Boletín Oficial de las Diócesis de Pamplona y Tudela (noviembre 2006): 1.403-1.406.

135 Herrán y Fernández, Kerigma (Casals), 30. También García Inza y Herrán, Fe y vida (Magisterio), 71.

136 Cortés, Cortés y Forcada, Religión católica (SM), 28; Q. Calvo, P. P. Abad y A. A. Cuadrón de Mingo, La buena noticia de Jesús de Nazaret en la Iglesia, 2. ${ }^{\circ}$ FP (Estella: Verbo Divino, 1985), 93.

137 Javier Segura (coord.), Tras las huellas de Javier. El hombre que abrazó el mundo. Segundo Ciclo ESO (Berriozar: Cénlit, 2005), 41, 55-56, 60-61; Edice, El encuentro con Dios a través de la Historia, 3. ${ }^{\circ}$ ESO (Madrid: Editorial de la Conferencia Episcopal Española, 1995), 53.

138 A. Fernández y P. de la Herrán, Kairós. Religión católica, 3. ESO (Barcelona: Casals, 2004), 37; A. López Quintela, M. Martín y J. Sorando, Religión. Bachillerato (Barcelona: Edebé, 2000), 19.
} 
víctimas: como mucho, las editoriales aggiornate lamentan la intolerancia: ${ }^{139}$ la (temida) verdad historiográfica ayudaría al diálogo de que hablan. La crítica que plantea EDICE al islam es su «acentuado fatalismo»; Everest insiste en el integrismo y terrorismo islámicos y en la oleada migratoria magrebí que va «salpicando de mezquitas y hiyabs nuestros paisajes urbanos». ${ }^{140} \mathrm{El}$ islam siempre se asocia, especialmente en las editoriales neointegristas, a «invasión» (de la Península Ibérica del año 711) y «grave peligro», a que ponen fin la Reconquista (las operaciones militares de los reinos cristianos del norte para recuperar el territorio peninsular), las Cruzadas,... ${ }^{141}$ Sólo de forma esporádica se ofrece una imagen más amable de Mahoma, defensor de los pobres. ${ }^{142}$

Las definición de la herejía como «explicación parcial» de la Verdad (Casals) o como «doctrina errónea» (Everest), indica que el miedo a la misma persiste. Ese miedo lleva a Anaya a justificar la intransigencia: «Era tanta su fe en Jesucristo como verdadero hombre y verdadero Dios que [Nicolás de Bari] evitó que en su diócesis [Mira] se produjera la herejía arriana, según la cual se negaba la divinidad de Jesucristo». ${ }^{143}$ La Iglesia sólida (Casals) considera la herejía valdense "perniciosa» y la Inquisición «comprensible en aquella época». Aguaclara, que tampoco cree lícito analizar la Inquisición «desde nuestro tiempo», la explica porque «los reyes» veían en las herejías «desórdenes». ${ }^{144}$ La Iglesia líquida, que también achaca la intolerancia a la influencia del poder civil, se distingue por insistir más en la crueldad inquisitorial. ${ }^{145}$

La Iglesia sólida asocia la reforma protestante con peligro. La editorial Magisterio, en el mejor estilo de Paul Hazard (que no cita), valora como

139 Fernández y Herrán, Kairós (Casals), 174; Herrán et al., Kairós. Religión católica, 4. ${ }^{\circ}$ ESO (Barcelona: Casals, 2005), 71; M. Bello Sánchez, Religión, 3. ${ }^{\circ}$ ESO (Madrid: Anaya, 1998), 95; Cortés, Forcada y Castaño, Religión, 4. ${ }^{\circ}$ ESO (SM), 82.

140 Edice, El encuentro, 59; Proyecto Deba, Religión, 4. ${ }^{\circ}$ ESO (León: Everest, 2007), 48, 96.

${ }^{141}$ Fernández y Herrán, Kairós (Casals), 172.

${ }^{142}$ López Quintela, Martín y Sorando, Religión (Edebé), 20.

${ }^{143}$ P. de la Herrán et al., Kairós. Religión católica, 4. ${ }^{\circ}$ ESO (Barcelona: Casals, 2005), 36; Proyecto Deba, Religión católica, $4 .^{\circ}$ ESO (León: Everest, 2007), 36; Valero Crespo, Religión católica, $1 .^{\circ}$ ESO, (Madrid: Anaya, 2007), 58-59.

144 Herrán, et al., Kairós (Casals), 71; J. C. Sampedro et al., Religión y moral católicas. Un pueblo en camino, 2. ${ }^{\circ}$ BUP (Alicante: Aguaclara, 1984), 37.

${ }^{145}$ Cortés, Forcada, Castaño, Religión (SM), 82; A. González Fraile, Somos Iglesia. 2. ${ }^{\circ}$ BUP (Madrid: Ediciones Paulinas, 1983), 44-45. 
nefastas sus consecuencias: guerras de religión, «ruptura de la conciencia europea», hilando el protestantismo con el racionalismo. Casals presenta, como los manuales del pasado, a Lutero como un personaje «agresivo» (idea que refuerza con una pintura de P. Thumann: «Lutero tira la bula papal de excomunión»), su doctrina sobre la predestinación como el resultado de un problema personal, y su expansión como fruto del apoyo de los príncipes alemanes, como si el catolicismo no hubiera contado con el apoyo de los Austrias. ${ }^{146}$ La Iglesia líquida (SM) teme menos reconocer los problemas internos de la Iglesia. Incluso comprende la actitud de Lutero ante el escándalo de las indulgencias: «apoyándose en los escritos del Nuevo Testamento, pensaba que nadie puede comprar con dinero la gracia y la salvación, sino que Dios la da gratuitamente». ${ }^{147}$ Refleja mejor el espíritu ecuménico y un temor menor al diálogo con el otro.

\section{El miedo a las novedades del Concilio Vaticano II}

Las dos subculturas católicas valoran de forma distinta el Vaticano II. La revista Razón y Fe, en pleno proceso de aggiornamento de la Iglesia española que coincide con la crisis del régimen franquista, se posiciona en favor de la democratización de la Iglesia, respetando el principio de autoridad. ${ }^{148}$ Pero la jerarquía integrista expresa el miedo a los cambios: en 1965 alerta sobre la infiltración en la Iglesia de un «criticismo exagerado», de un «ideario peligrosísimo» que afirma que la Verdad no la posee nadie o que el capitalismo es peor que el comunismo. ${ }^{149}$ Años más tarde, la Iglesia neointegrista recoge esos temores. Benedicto XVI, en el 40 aniversario del Concilio, más que en los cambios que éste supuso, se centra en que Pablo VI declaró a María protectora del mismo. ${ }^{150}$ La Congregación para la Doctrina de la Fe condena los «errores» de Jon Sobrino sobre «la Iglesia de los pobres». ${ }^{151}$ La Conferencia Episcopal Española, controlada desde 1985 por los sectores más conser-

\footnotetext{
146 G. Lobo Méndez, Por qué soy cristiano. El hombre y el mundo actual. Religión 3. ${ }^{\circ}$ BUP (Madrid: Magisterio, 1977), 405-406; Herrán et al., Kairós... (Casals), 82-83.

147 Cortés, Forcada, y Castaño, Religión (SM), 78-79. También: M. Bello, Religión católica, $4 .^{\circ}$ ESO (Madrid: Anaya, 1995), 66-68.

148 Razón y Fe, 881, tomo 183 (junio 1971): 563-568.

149 Boletín Oficial de las Diócesis de Pamplona y Tudela, 5 (mayo 1965): 73-84.

150 Boletín Oficial de las Diócesis de Pamplona y Tudela (enero 2006), 138-145.

151 Boletín Oficial de las Diócesis de Pamplona y Tudela (abril 2007), 559.
} 
vadores, alerta contra los católicos favorables al sacerdocio femenino y al matrimonio homosexual. ${ }^{152}$

De igual manera, los manuales neointegristas, impelidos por el miedo al cambio, insisten en la permanencia de la institución: la Iglesia «sigue» predicando el Evangelio, tiene los mismos sacramentos (Magisterio). Casals identifica el Postconcilio con «tiempo de crisis en la Iglesia»: «abusos», "espíritu revolucionario» de la teología de la liberación. ${ }^{153}$ La Iglesia líqui$d a$, menos temerosa, insiste en los cambios. Para Santillana, el Concilio reflexionó sobre el papel de la Iglesia en el mundo, la opción por los pobres. No faltan contradicciones. SM critica la actitud «regresiva» de los sectores de la Iglesia que, por "miedo», desearían volver al pasado, mientras ve en Juan Pablo II la defensa de «los derechos del hombre y la necesidad de justicia en una línea similar al Vaticano II», imagen poco convincente que expresa el miedo de los manuales aggiornati a romper la jerarquía y la unidad (como los neointegristas). ${ }^{154}$

\section{El miedo al desmoronamiento de la cultura}

A pesar de la autonomía que el Vaticano II dice dar al pensamiento y a la ciencia, los documentos eclesiales alertan contra la «pretensión totalizante de la ciencia» y las teorías evolucionistas que excluyen un Ser trascendente. ${ }^{155}$ Se reconoce el valor de la ciencia para estudiar «los fenómenos humanos», pero añadiendo que no puede «explicar todo el hombre ni toda la historia» y es incapaz «de llegar a la profundidad decisiva del corazón y de la conciencia». Es el principio MANOS (Magisterios No Solapables): fe y ciencia nunca colisionan. ${ }^{156}$ El discurso de Benedicto XVI en Ratisbona en 2006, más allá de polémicas, defiende que la Iglesia logró la síntesis entre la fe y la razón, logro que frustró el protestantismo y la teología liberal del siglo XIX: sólo se superarán los peligros de la modernidad si la fe y la razón avanzan juntas; sólo habrá diálogo intercultural si la razón deja de ser sorda

\footnotetext{
152 Boletín Oficial de las Diócesis de Pamplona y Tudela (mayo 2006), 656.

153 Lobo, Por qué soy (Magisterio), 410-413; Herrán et al., Kairós (Casals), 149-152.

${ }^{154}$ F. Puértolas et al., Jerusalén. Religión y moral católica, $4 .{ }^{\circ}$ ESO (Madrid: Santillana, 2006), 90-91; J. Cortés, T. Domingo y J. C. Flores, Sociedad, Cultura y Religión (Madrid: SM, 1998), 98.

155 Boletín Oficial de las Diócesis de Pamplona y Tudela (marzo 2006): 344 y (febrero 2007), 267-268.

156 Boletín Oficial de la Archidiócesis de Madrid-Alcalá, 3 (1 febrero 1974): 168, 173. Sobre MANOS: Richard Dawkins, El espejismo de Dios, 64-71, 130-148.
} 
a lo divino. ${ }^{157}$ La Conferencia Episcopal Española en 2006 lamenta que en el estudio de los textos bíblicos se empleen métodos científicos «en los que se excluye la posibilidad de la Revelación, del milagro»: ${ }^{158}$ para que fe y razón no entren en conflicto, la ciencia debería aceptarlos.

El mismo miedo expresan los manuales neointegristas, que no pierden el modelo escolástico. Para Magisterio, el Humanismo y Reforma significan la «ruptura de la conciencia europea»; la Ilustración, la aplicación de «principios racionalistas estrictos a la sociedad y al individuo para alcanzar la felicidad». EDICE afirma que «el culto a la razón induce a un violento rechazo de la religión y con ella de la Iglesia»: la modernidad, sin Dios, significa violencia. No reconocen virtud alguna en el pensamiento contemporáneo. Para Magisterio, Marx pone la liberación del hombre sólo en lo económico; Freud mitifica el instinto y minimiza la libertad; Nietzsche da al hombre un poder absoluto; los estructuralistas lo ven como mero efecto de las estructuras sociales; Sartre, como pasión inútil; Camus rechaza el sentido del dolor. ${ }^{159}$

La Iglesia líquida no se centra en los efectos perniciosos de la secularización. SM no refiere un pasado modélico al que volver (la Escolástica), pero, olvidando la faceta más intransigente de la Iglesia, pone el foco en sus intentos de diálogo con la modernidad y en sus «movimientos de renovación». Afirma la posibilidad de reconciliación entre fe y razón, como hicieron los ilustrados católicos. Santillana ve en la Ilustración un «reto para depurar el cristianismo de creencias y costumbres que no respondían al mensaje del Evangelio». Reconoce algún mérito en el pensamiento moderno. Para Aguaclara, Marx descubre la alienación; Freud, el subconsciente; Nietzsche, el amor a la vida; el existencialismo, la pregunta sobre la existencia; el estructuralismo, los condicionamientos humanos, pero critica el materialismo, pansexualismo e irracionalidad de estos movimientos. ${ }^{160}$

Los manuales neointegristas centran su mensaje en los peligros de la ciencia. Para Magisterio, «crea en el hombre moderno una mentalidad de

\footnotetext{
157 Boletín Oficial de las Diócesis de Pamplona y Tudela (noviembre 2006): 1457-1465.

158 Boletín Oficial de las Diócesis de Pamplona y Tudela (mayo 2006): 644.

159 Lobo, Por qué soy (Magisterio), 28, 91, 99, 134, 170, 183, 189, 226, 406-408; Edice, El encuentro, 143. También: Herrán y Fernández, Kerigma (Casals), 12-13, 42-43.

160 Cortés, Forcada y Castaño, Religión (SM), 91; F. Puértolas et al., Jerusalén (Santillana), 72; J. C. Sampedro et al., Nosotros, nuestro mundo, nuestra fe. Religión y moral católicas, 3. ${ }^{\circ}$ BUP (Alicante: Aguaclara, 1988), 39-49, 60, 62. También: J. Cortés y G. Castaño, Religión católica. Bachillerato (Madrid: SM, 2008), $24-27$.
} 
poder y suficiencia y una psicología de placer y comodidad». Los aggiornati, menos temerosos, ven más posibilidades de conciliación entre ciencia y religión: Ediciones Paulinas también considera que la ciencia es «insuficiente» para dar sentido a la vida y genera peligros (autosuficiencia, ambición de poder,...), pero también que acarrea ventajas a la propia fe, pues ayuda a superar lo mágico y supersticioso. ${ }^{161}$

El criterio MANOS es el artefacto que permite disimular el miedo a la ciencia. Para Anaya, los malentendidos entre ciencia y religión ya están superados pues abordan campos «claramente delimitados». Para Santillana, se complementan: la ciencia aclara el cómo y la fe el porqué y el para qué. Para SM, «no hay contradicción» entre ambas «si cada una respeta la autonomía en el campo propio, y las fuentes de las respuestas de la otra» ( ¿las fuentes de la revelación podrán ser objeto de estudio científico?): la religión garantiza su supervivencia si se convierte en filosofía de la ciencia. ${ }^{162}$

\section{El miedo al desmoronamiento de la sociedad}

El Vaticano II crea una nueva sensibilidad social. En 1971 la Asociación Católica Nacional de Propagandistas, una agrupación de seglares católicos creada en 1909 para difundir los valores más tradicionales de la Iglesia católica española, reconoce que las estructuras sociales condicionan la vida y la necesidad de mejorarlas. La Iglesia sólida da un giro conservador: Monseñor Sebastián, obispo de Pamplona, al comentar la encíclica de Benedicto XVI Deus caritas est, olvida las estructuras, reivindica la caridad y moraliza sobre el origen de los problemas sociales: «donde no hay fe ni vida cristiana, el desconcierto moral, la corrupción y los abusos crecen y se multiplican». ${ }^{163}$

Los manuales, de hecho, siguen viendo la realidad desde una perspectiva espiritualista, a pesar de que Bruño afirme que la Iglesia ha superado el platonismo y ha recuperado el valor del cuerpo. Siguen temiendo el cuerpo, el placer. SM exalta la castidad y Casals el dolor inevitable, que no han re-

\footnotetext{
161 Lobo, Por qué soy (Magisterio), 47; Carlos J. Manjares y A. J. Fraile, Fe cristiana y mundo moderno, 3. ${ }^{\circ}$ BUP (Madrid: Ediciones Paulinas, 1985), 12-15.

162 Bello, Religión, 3. ${ }^{\circ}$ ESO (Anaya), 18; Piédrola e Ibáñez, Religión, $6^{\circ}$ EGB (Santillana), 142; J. Cortés y M.A. Cortés, Fe y sentido de la vida. Religión católica, 3. ${ }^{\circ}$ BUP (Madrid: SM, 1991), 126.

163 Boletín Oficial de las Diócesis de Pamplona y Tudela, 6 (junio 1971): 299 y (abril 2006): 448.
} 
mediado la ciencia o el comunismo. ${ }^{164}$ En los neointegristas (Magisterio-Casals) hay una amplia lista de condenas: no temen evidenciar su oposición a la legalización del divorcio, los métodos anticonceptivos, el matrimonio homosexual... Los más aggiornati (Anaya, SM) se distinguen por considerar que la sexualidad ha sido creada por Dios (para procrear), por evidenciar la necesidad de la educación sexual, por hablar en positivo (matrimonio heterosexual y definitivo) más que de prohibiciones, aunque ofrezcan una visión reduccionista de la masturbación como desahogo propio de la adolescencia, o de la homosexualidad como producto de condiciones medioambientales que puede corregirse. ${ }^{165}$

El miedo a la mujer es menor en las editoriales aggiornate. Pero, al dar una visión más abierta del género, trastocan más la historia. Edebé, al indicar sólo que Jesús defendió a las mujeres, borra varios siglos de historia de las mentalidades, definidos por una desigualdad condicionada en gran medida por la Iglesia. Anaya desmiente que el episodio de la creación de la mujer justifique la desigualdad de género (en realidad fue así). Casals, en cambio, legitima las «diferencias específicas» de la mujer (maternidad, sustento de la familia y la sociedad) o que la Iglesia no puede ordenar a mujeres: Jesús sólo ordenó varones. Las editoriales más aggiornate no se atreverían a afirmar tampoco, como hace Magisterio, que María era «la esclava del Señor», que hacía «la mayor parte de los trabajos de la casa». ${ }^{166}$

Además del miedo a la pérdida de valores morales, se mantiene el miedo al desmoronamiento de la estructura social. Los problemas sociales se siguen analizando desde una perspectiva moralista, olvidando lo sistémico: para Magisterio, «la codicia de muchos amos llevaba a hacer trabajar a los esclavos en condiciones infrahumanas». Santillana recuerda el carácter indiferente de la riqueza para alcanzar la salvación. El desprecio por lo material puede expresarse con arrojo: dice Dios a los hombres en una viñeta de SM: «No andéis agobiados por la vida pensando qué vais a

164 Egea, et al., Experiencia (Bruño), 146-149; J. Cortés y G. Castaño, Religión (SM), 160; Herrán y Fernández, Kerigma (Casals), 70-74.

165 García Inza y Herrán, Fe y vida (Magisterio), 102-103, 108; Herrán y Fernández, Kerigma (Casals), 101-102; Valero Crespo, Religión católica, $1 .^{\circ}$ ESO (Madrid: Anaya, 2007), 121; G. Castaño y J. Cortés, Religión católica. Bachillerato (Madrid: SM, 1998), 174-179; Cortés y Castaño, Religión (SM), 151, 153-155. ${ }^{166}$ Religión, 6. ${ }^{\circ}$ Primaria (Edebé), 53, 65; Valero Crespo, Religión, $1 .{ }^{\circ}$ ESO (Anaya), 123; Herrán y Fernández, Kerigma (Casals), 109; P. de la Herrán y Ll. Fabregat, Kairós. Religión católica, $1{ }^{\circ}$ ESO (Barcelona: Casals, 2004), 138; Fernández y Herrán, Kairós. $3^{\circ}$ ESO (Casals), 113; García Inda y Herrán, Fe y vida (Magisterio), 18-19. 
comer o a beber; ni por el cuerpo [...] ¿No vale más la vida que el alimento, y el cuerpo más que el vestido? Son los paganos los que ponen su afán en estas cosas». ${ }^{167}$

Los manuales de Religión conservan el miedo al presente que caracterizaba al integrismo. Bruño (2. ${ }^{\circ}$ Bachillerato), que tiene como referente el supuesto equilibrio gremial del Antiguo Régimen, considera que la situación social «se complica» en la Edad Contemporánea. En otros, incluso de la misma editorial, sobre el miedo al presente se impone el miedo al cambio social. Sitúan al alumno en un nuevo locus temporal, el de la sociedad satisfecha que ha superado un pasado problemático. Dice Bruño en referencia a la esclavitud, el feudalismo y el primer capitalismo: «Muchos de nuestros antepasados han vivido sometidos a estructuras sociales injustas, que lesionaban gravemente los derechos fundamentales de las personas». ${ }^{168}$

Esporádicamente encontramos actitudes más libres. Ediciones Paulinas recuerda que el racismo, el nepotismo, el clasismo son contrarios al «amor universal»: el privilegio de unos es opresión para otros. En una entrevista que reproduce Edebé, el misionero Francisco Balauder habla del sufrimiento de los africanos, cuyo silencio se explica por el «miedo» a la autoridad, y apela a que tomen "conciencia de lo que son, de sus derechos». ${ }^{169}$ Se trata de un tamizado - y heteróclito - reflejo de la penalizada teología de la liberación, más dispuesta a buscar las causas del mal social en las estructuras y no en el pecado y a referir el uso político del miedo.

El miedo al hundimiento del statu quo supone condenar sistemas sociales alternativos, esencialmente el marxismo. Los manuales neointegristas continúan la senda de los integristas. Para Magisterio, es materialismo, violencia revolucionaria, odio, miedo. Casals, además, recalca la condena que hacen los distintos papas al comunismo por «sus errores doctrinales», $\mathrm{y}$ plantea a los alumnos preguntas como: «¿Por qué se ha dicho que, en Marx, el odio es el motor de la historia?». ${ }^{170}$

167 García Inza y Herrán, Fe y vida (Magisterio), 114; Piédrola y Ibáñez, Religión $6 .{ }^{\circ}$ EGB (Santillana), 53; Cortés, Cortés y Forcada, Religión (SM), 17.

${ }^{168}$ M. A del Barrio et al., Religión católica. Protagonistas de la Historia, 2. ${ }^{\circ}$ Bachillerato (Madrid: Bruño, 2000), 41; Egea et al., Experiencia (Bruño), 293-296.

169 González Fraile, Somos Iglesia (Ediciones Paulinas), 125-126; López Quintela, Martín y Sorando, Religión (Edebé), 98-101.

${ }^{170}$ Lobo, Por qué soy (Magisterio), 152, 147, 161; Herrán et al., Kairós (Casals), 124, 136-137. 
Algunas editoriales próximas en este punto a la Iglesia líquida, como Everest, parecen perder el miedo a reconocer que el «miedo al comunismo» impidió a la Iglesia una condena más clara del fascismo. Ediciones Paulinas abre una vía de entendimiento con el marxismo y recurre a la conocida dicotomía entre sus «aciertos» (descubrir las «inmensas lacras» del capitalismo) y sus debilidades: «explicación superficial» del mal (burguesía) y del bien (proletariado). Santillana no anatemiza al socialismo, que pretende «construir una sociedad más justa mediante la propiedad social de los bienes de producción». SM, después de refutar la visión marxista de la religión como opio del pueblo, afirma que el marxismo «aporta» la crítica a una manera de vivir la fe al margen de la realidad e indiferente a las injusticias. No inculca antimarxismo. ${ }^{171}$

La garantía de conservación del orden social es la doctrina social de la Iglesia. Los manuales neointegristas tienen como referencia la encíclica Rerum Novarum, que permite los sindicatos «que no atent[en] contra la vida social»(Casals). Espiritualizan el mensaje: para Verbo Divino, la doctrina social de la Iglesia tiene como primer objetivo la salvación espiritual del hombre amenazado por el materialismo. Las editoriales aggiornate expresan una menor agresividad hacia el marxismo y una menor tendencia a disolver los problemas sociales en cuestiones morales. Edebé señala que la Iglesia propone un «mejor reparto de bienes», la eliminación de «las grandes bolsas de pobreza». SM recoge las facetas más progresistas de las encíclicas más recientes: Pacem in Terris (defensa de la paz como fruto de la justicia), Populorum Progressio (transformar la economía del tercer mundo). ${ }^{172}$

\section{El miedo al desmoronamiento político: el laicismo}

La encíclica Redemptor Hominis de Juan Pablo II denuncia, sin datos concretos, «la postura según la cual sólo el ateísmo tiene derecho de ciudadanía en la vida pública, mientras los hombres creyentes, casi por princi-

\footnotetext{
171 Proyecto Deba, Religión (Everest), 93; Manjarés y Fraile, Fe cristiana (Ediciones Paulinas), 37-38; E. Piédrola y J. Olóriz: Religión, $7 .^{\circ}$ EGB (Madrid: Santillana, 1988), 84-85; Cortés y Cortés, Fe y sentido (SM), 137-138.

172 Herrán et al., Kairós (Casals), 125; Calvo, Abad y Cuadrón de Mingo, La buena noticia (Verbo Divino), 28-30, 97-102; G. Ruiz et al., Religión católica, $4 .{ }^{\circ}$ ESO (Barcelona: Edebé, 1996), 106-107; Castaño, Cortés y Cortés, Betel (SM), 61.
} 
pio, son apenas tolerados» o "privados totalmente de los derechos de ciudadanía». ${ }^{173}$ La jerarquía católica alerta una y otra vez contra la mentalidad laicista que «impide» la manifestación de las convicciones religiosas. En la mentalidad eclesial, el laicismo siempre incluye violencia, mientras la Iglesia sólo pretende que el católico «hable y actúe en la vida pública». ${ }^{174} \mathrm{El}$ obispo de Pamplona, Fernando Sebastián, buen representante de la Iglesia sólida, durante los gobiernos del socialista José Luis Rodríguez Zapatero (aprobación del matrimonio homosexual), insiste una y otra vez en que los gobernantes no pueden gobernar sin tener en cuenta la «moral natural» y la «moral histórica de nuestra sociedad»: el comunitarismo nacional-católico. ${ }^{175} \mathrm{E}$ incluso habla de «un laicismo agresivo y militante, que causa crecientes dificultades para la vida de la Iglesia y de los católicos», que, al intentar volver al anticlericalismo de la II República, amenaza el consenso democrático que la Iglesia contribuyó a establecer. ${ }^{176}$

Los manuales también dan una explicación interesada del laicismo. Los neointegristas (Casals) hacen disquisiciones sobre el «Estado laico» respetuoso con las religiones, y el «Estado laicista», que pretende «borrar cualquier símbolo religioso de la vida pública, como si fuera algo que hay que relegar a la vida privada». No aclara cuáles son los Estados a los que se podría atribuir uno u otro adjetivo: lo esencial es justificar la presencia de la religión «en el orden social», sin marcar límites, en nombre de la hasta ahora denostada libertad religiosa. Anaya mete a los «grupos laicistas» — sin identificar- en el mismo saco que el racismo, la perversión y la violencia. ${ }^{177}$

Todas las editoriales legitiman el derecho de la Iglesia a intervenir en la vida pública. Las de la Iglesia sólida, más beligerantes, pretenden imponer una moral exterior, prepolítica, en la legislación del Estado. Magisterio hace elenco de las «incompatibilidades» con la fe: divorcio y aborto, soluciones materialistas (capitalismo liberal, comunismo, revolución y terrorismo). Casals recuerda que las decisiones políticas deben ajustarse a la «ley natural» anterior al Estado: derecho a la vida, libertad de educación de los

\footnotetext{
173 Boletín Oficial de las Diócesis de Pamplona y Tudela (4, abril 1979): 180-181.

174 Boletín Oficial de las Diócesis de Pamplona y Tudela (mayo 2006): 657, 662.

175 Boletín Oficial de las Diócesis de Pamplona y Tudela (octubre 2006): 1.211.

176 Boletín Oficial de las Diócesis de Pamplona y Tudela (marzo 2007): 351-352.

177 Herrán y Fernández, Kerigma (Casals), 154; Crespo, Religión, 1. ${ }^{\circ}$ ESO (Anaya), 36.
} 
padres, protección de la familia, propiedad privada,... Según el principio de subsidiariedad, «el Estado no puede suplantar los derechos de las personas y de las familias». ${ }^{178}$

Casals formula este principio en términos económicos: «no debe intervenir el Estado cuando la iniciativa privada puede hacerlo». Larrauri, en términos educativos: los padres son los primeros responsables de la educación, la función del Estado «es subsidiaria o de ayuda» (crear centros, subvencionar otros), la Iglesia "participa» a través de sus centros y «ofreciendo la posibilidad de una formación en consonancia con sus ideales». Y Anaya, en términos políticos: «la sociedad necesita de la religión: de sus símbolos, valores y creencias»; los católicos deben «votar y apoyar a partidos políticos que defiendan programas de apoyo a las familias y a sus derechos». ${ }^{179}$

La Iglesia líquida establece menos marcajes a la autonomía estatal. Ediciones Paulinas formula esa «ley natural» en abstracto: defensa de la vida, justicia distributiva, oposición al totalitarismo, libertad, paz, derechos humanos, protección de la familia, atención a los más débiles. ${ }^{180}$ Todas las editoriales, en mayor o menor grado, justifican la presencia pública de la religión. Pero ninguna plantea la «traducción cooperativa» de que habla Habermas: al igual que Joseph A. Ratzinger, entienden la moral cristiana como un mínimo ético anterior al Estado, al que éste debe someterse. La Iglesia niega al Estado autonomía decisional. ${ }^{181}$ Como los mercados.

Los manuales expresan el miedo a cualquier régimen que altere esa «ley natural». Los de la Iglesia sólida, dan una visión catastrofista de la Revolución francesa. Casals y Verbo Divino observan la transformación de ideales nobles (libertad, igualdad, fraternidad) en guillotina, asesinato de curas,...: la revolución es el Mal, aunque comience en un sentido moderado. Los aggiornati (SM) diferencian consecuencias «positivas» (Declaración de Dere-

\footnotetext{
178 Lobo, Por qué soy (Magisterio), 482-484; Herrán y Fernández, Kerigma (Casals), 100-102, 153.

179 Martínez García, Kairós (Casals), 135; Zalbide, El adolescente (Larrauri), 55, 123-124; Crespo, Religión 1. ${ }^{\circ}$ ESO (Anaya), 18-19, 133.

180 González Fraile, Somos Iglesia (Ediciones Paulinas), 227, 221-222. También: G. Ruiz et al., Religión católica, 4. ${ }^{\circ}$ ESO (Barcelona: Edebé, 1996), 111.

181 Jürgen Habermas, «¿Fundamentos prepolíticos del Estado democrático de derecho?», en Entre razón y religión. Dialéctica de la secularización, Jürgen Habermas y Joseph Ratzinger (México: F.C.E, 2008), 9-33; Joseph Ratzinger, «Lo que cohesiona al mundo. Los fundamentos morales y prepolíticos del Estado liberal», en Entre razón y religión, 35-54.
} 
chos) y negativas: querer eliminar «todo recuerdo del pasado, incluida la religión». Añade una vaga referencia (¿autocrítica?) a la alianza de la Iglesia con los que «se oponían a la revolución» sin explicar por qué. ${ }^{182}$

Anaya identifica a las reformas del primer bienio izquierdista (19311933) de la II República española (educación laica, supresión del pago de culto y clero por el Estado,...) con «una actitud antirreligiosa y anticlerical que conduce a la quema de iglesias y conventos». Laberinto, igualmente, pone en el mismo plano la quema de conventos realizada por grupos radicales en mayo de 1931 y las disposiciones del gobierno. La aggiornata SM, aunque reparta culpas (Iglesia y gobierno «extremaron sus posturas»), habla de «ataque» a la Iglesia y «a la religiosidad», mezcla violencia anticlerical con las medidas gubernamentales, culpa al laicismo de la Guerra Civil y afirma que las medidas del gobierno iban destinadas a «declarar a España, y no sólo al Estado Español, como laica». El miedo así sirve para legitimar el apoyo de la Iglesia al golpe militar de Franco contra la República (1936) y ocultar sus intereses: control de las conciencias, defensa de privilegios históricos. ${ }^{183}$

\section{El miedo a la pérdida de influencia en la sociedad y de capacidad económica}

La insistencia en la amenaza de la modernidad significa el miedo de la Iglesia a perder influencia y capacidad económica. Con matices. El primer referente de la Iglesia líquida, el cardenal Tarancón, en 1974 habla de «evitar en lo posible» la dependencia económica del Estado; la Iglesia sólida, se aferra a la donación «libre y voluntaria» de bienes que los pueblos hicieron a la Iglesia o a los acuerdos Iglesia-Estado para mantener el patrimonio artístico. ${ }^{184}$

La preocupación crematística es también eje fundamental de los manuales. Verbo Divino justifica — y sublima— el origen del patrimonio eclesiásti-

\footnotetext{
182 Herrán et al., Kairós (Casals), 114-115; Calvo, Abad y Cuadrón de Mingo, La buena noticia (Verbo Divino), 96-97; Cortés, Forcada y Castaño, Religión (SM), 94-95.

183 Bello, Religión $3 .^{\circ}$ ESO (Anaya), 147; J. A. Vela, Sociedad, cultura y Religión, 2. ${ }^{\circ}$ Ciclo ESO (Madrid: Laberinto, 2005), 157; Cortés, Domingo y Flores, Sociedad, cultura (SM), 108; Cortés, Forcada y Castaño, Religión (SM), 110.

${ }_{184}$ Boletín Oficial de las Archidiócesis de Madrid-Alcalá, 5 (1 marzo 1974): 250, y Boletín Oficial de las Diócesis de Pamplona y Tudela (mayo 2007): 633-634.
} 
co «por las obligaciones de los fieles y por las donaciones de los emperadores». Laberinto, de forma excepcional, alude a la falsedad de la donación de Constantino, pero no para aclarar los intereses que la movieron, sino para legitimar el resto de donaciones: «El citado documento era, como se probó en el Renacimiento, una falsificación [...]. En cualquier caso, los emperadores franceses y alemanes confirmaron e incluso ampliaron la supuesta donación». También se sublima la desamortización y la pérdida de los Estados Pontificios, que significaron la espiritualización y la «despolitización de la Iglesia» (Verbo Divino). ${ }^{185}$

\section{REFLEXIÓN FINAL}

Respecto a la Iglesia integrista, en la Iglesia actual, que alude más a la esperanza y a la vida, pierden peso la necesidad de aplacar la ira de Dios (Dios ya no domina la naturaleza) y los miedos escatológicos (Juicio Final, Infierno,...). El ecumenismo, con todas sus contradicciones, reduce la dosis de miedo al otro; la Iglesia líquida, con todos los matices que se quiera, parece haber perdido el miedo al diálogo con la modernidad, que la entiende más como reto que como peligro. Pero el miedo, ya desposeído de cualquier matiz sensitivo, sigue presente, sobre todo en los manuales de la Iglesia sólida: miedo a la teología de la liberación, a la penetración del marxismo en la Iglesia, al desmoronamiento y secularización de la cultura, a la pérdida de influencia en la sociedad, a la pérdida de protección por parte del Estado. Los autores de manuales expresan los mismos miedos que la jerarquía en los boletines y revistas eclesiales: su metadiscurso es nulo.

Según José V. Casanova, el aggiornamento transforma la Iglesia «de una institución estatalmente orientada a otra orientada a la sociedad», para lo que predica la dignidad de la persona, la naturaleza sacramental del trabajo [...] frente al materialismo, el individualismo y la anomia moderna. ${ }^{186}$ En todo caso, no parece tan obvio que la Iglesia haya perdido la orientación estatal que tuvo en el integrismo: al menos a través de los manuales de Religión, sigue demandando que el Estado garantice su presencia en la sociedad. Las editoriales aggiornate y neointegristas lo demandan de dis-

\footnotetext{
185 Calvo, Abad y Cuadrón de Mingo, La buena noticia (Verbo Divino), 58, 96-97; Vela León, Sociedad, Cultura (Laberinto), 52-53. También: Lobo, Por qué soy (Magisterio), 409.

186 Casanova, Genealogías de la secularización, 204-205, 258.
} 
tinta manera. Entre las primeras, Santillana, al abordar el tema de las relaciones Iglesia-Estado español en la actualidad, habla del «respeto mutuo», de «colaboración», de "acciones conjuntas de tipo social y cultural» entre ambos, como si, superado el conflicto histórico confesionalidad-laicismo, se hubiera alcanzado el equilibrio ansiado: esta visión tan plana tiene la virtud de ocultar los sustantivos privilegios de la Iglesia española actual (subvención estatal de centros privados —-mayoritariamente católicos-, profesores de Religión en los centros públicos pagados por el Estado, exención de impuestos sobre bienes inmuebles,...). Manuales más cercanos al neointegrismo como el de Laberinto afirman que la Constitución de 1978, actualmente en vigor, reconoce «la importancia social del catolicismo frente a otras religiones» y el "fundamento constitucional» de que «la Iglesia reciba un tratamiento por parte del Estado distinto al que reciben otras religiones», lo que determina la «obligación del Estado a garantizar» el derecho de los padres a «elegir educación religiosa y moral de sus hijos», la «dotación presupuestaria»: es la visión maximalista de los derechos que otorga la Constitución a la Iglesia (en realidad, más que la Constitución, los Acuerdos de 1979 entre España y la Santa Sede), amparados en una especie de nacionalcatolicismo sociológico. Larrauri, al abordar el mismo punto, recuerda a los alumnos que, aun respetando la autonomía del Estado, la Iglesia, que salvaguarda el carácter trascendente de la persona, «se sitúa en un plano superior al meramente material y temporal», que es el que corresponde al Estado. ${ }^{187}$

La Iglesia, para mantener esa influencia, debe recurrir al olvido, la ocultación o a la distorsión de la realidad. Tiene que ocultar que, para ejercer el control social, ha utilizado el miedo. Rechaza la imagen ridícula del demonio, como si esa imagen no la hubiera creado nadie. Oculta que la Iglesia ha utilizado el arte para inculcar miedo: sistemáticamente los manuales de Religión afirman que las artes plásticas del Románico servían «para enseñar al pueblo, en su mayoría analfabeto». ${ }^{188}$ Oculta que el miedo al judío, que está detrás de pogromos y expulsiones, es una creación cristiana. Ofrece una imagen violenta de la secularización y el laicismo, para justificar su presencia en una sociedad que se dirige a la catástrofe sin Dios. Su miedo a la inmanencia, al protagonismo histórico del ser humano, se explica porque

187 Puértolas et al., Jerusalén (Santillana), 103; Vela, Sociedad, Cultura (Laberinto), 161-162; Zalbide, El adolescente (Larrauri), 123-124.

${ }^{188}$ Aldazábal, Mascaró y Montull, Religión (Edebé), 92. 
sólo la trascendencia, domine en ella la imagen de un Dios temible -integrismo- o amoroso — aggiornamento-, permite el protagonismo social y político de esa institución.

La Conferencia Episcopal Española, controlada a la altura del año 2006 por los sectores neointegristas, niega que la vida cristiana sea imposible en una sociedad democrática, al contrario de lo que afirman algunos sectores laicistas: "La historia demuestra que la democracia moderna nació en el ámbito de la cultura cristiana, en la que se han gestado el concepto de la persona como realidad trascendente y libre, la distinción entre la Iglesia y el Estado, con su autonomía recíproca, y la conciencia de los derechos humanos». ${ }^{189}$ Afirmaciones como ésta, que no tiene en cuenta lo que es un consenso entre muchos historiadores (la Iglesia ha sido baluarte principal contra la modernidad), nos hacen entender que uno de los sentimientos fundamentales que transmite la Iglesia es el miedo a la trabajosa búsqueda de la verdad. Se ha erosionado considerablemente el miedo a la coerción (al «coge intrare», "oblígales a entrar», agustiniano), pero no al olvido de la Verdad revelada (y de su portavoz). Ya lo dijo Agustín de Hipona: «Nisi credideritis, non intelligetis», "Si no creéis, no comprenderéis».

189 Boletín Oficial de las Diócesis de Pamplona y Tudela (enero 2007): 63. 


\section{Nota sobre el autor}

Emilio Castillejo Cambra autor es profesor de Historia en el IES Pedro de Ursúa de Pamplona y profesor-tutor del Centro Asociado de la UNED de Pamplona. Es Doctor en Historia por la Universidad Pública de Navarra (UPNA). Su labor investigadora se ha centrado en el análisis de los contenidos ideológicos de los manuales escolares tanto del pasado como de la actualidad. Entre otras publicaciones, destacan los libros Mito, legitimación y violencia simbólica en los manuales escolares de historia del franquismo, 1936-1975 (Madrid: UNED, 2008) y La enseñanza de la Religión católica en España desde la Transición (Madrid: La Catarata, 2012). 